症例

$$
\text { 小網裂孔へルニアの } 1 \text { 治験例 }
$$

須賀川病院外科
菊 地 洋 -
福島県立医科大学第 2 外科

安藤善郎吉田典行土屋敦雄阿部力哉

症例は腹部手術, 腹部外傷の既往のない78歳の女性で, 腹痛と嘔吐を主訴に来院した。 腹部は全体的に膨満し, 圧痛がみられ, 腹部単純 X 線像では上腹部に拡張腸管像が認め られ, CT では網衰と思われる部位に拡張腸管像が認められた.イレウスチューブを㨉入 したが，拡張腸管像は消失せず，内へルニアによるイレウスを疑い手術を施行した，開 腹すると小網に裂孔があり，約 $30 \mathrm{~cm}$ の小腸が網襄内に嵌頓していた，小腸に壊死はな く, 小網を一部切除し用手的に整復し, 術後は順調に経過した.

内ヘルニアはイレウスを起こす疾患としてまれなものであるが，われわれはその中で もさらにまれな小網異常裂孔による症例を経験したので文献的考察を加えて報告した。 小網裂孔へルニアは成因等不明な点が多いが, 診療方針は一般的なイレウスと差はない. イレウスの診療時には内へルニアの可能性を考慮におく必要があり, レントゲンやCT 等の特徽的所見に注意すべきと思われた。

卖引用語：内ヘルニア，小網裂孔，イレウス

\section{緒 言}

イレウスの原因として内へルニアはまれなものであ るが，その中でも小網裂孔によるものの数は少なく本 邦における報告はわずか数例のみである. 今回われわ れは小網裂孔による内へルニアが原因となるイレウス の症例を経験したので文献的な考察を加えて報告す る.

\section{症例}

患者：78墄，女性.

主訴：腹痛.

家族歴：特記すべきことなし。

既往歴：68歳時, 洞機能不全にてペースメーカーを 挿入した．69歳より高血圧症にて服薬中である．72歳 の時に解離性腹部大動脈瘤と診断されたが経過を観察 中である、腹部手術, 腹部外傷の既往はない。

現病歴：1994年 5 月29日就寝後に軽度の腹痛が出現 した.その後も腹痛持続し, 排便がなく軽食を摄取し て様子を見ていた。 5 月31日朝水分攝取後に嘔吐した ため当院を受診した。

入院時現症：体格はやせ型で,やや苦悶様であった

1994年10月27日受付 1995年 2 月16日採用
が、ショック症状はなかった，発熱はなく，費血もな かったが軽度の脱水があった.腹部は全体的に膨满し, 螦動不稳はなく，軽度の圧痛がみられたが，腹膜刺激 症状はなかった。腸雑音は低下していた。

検查所見：軽度の BUN, GOT の増加を認めたが, 白血球增加等の炎症所見はなかった(表 1). 腹部立位 正面単純 X 線像では, 上腹部に Niveau 形成を伴った 拡張した小腸像が認められた (図 1). 同日の腹部 CT

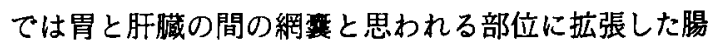
管像が想められ，また軽度の腹水が認められた(図 2). 大腸癌を否定するために行ったバリウム注腸検査では 盲腸部まで狭窄部位はなかった。

\section{表 1 検查所見}

\begin{tabular}{lc|lc}
\hline WBC & $7.600 / \mathrm{mm}^{3}$ & BUN & $27 \mathrm{mg} / \mathrm{dl}$ \\
$\mathrm{RBC}$ & $447 \times 10^{4} / \mathrm{mm}^{3}$ & Crea. & $1.3 \mathrm{mg} / \mathrm{dl}$ \\
$\mathrm{Hb}$ & $14.3 \mathrm{~g} / \mathrm{dl}$ & TP & $7.2 \mathrm{~g} / \mathrm{dl}$ \\
$\mathrm{Hct}$ & $41.9 \%$ & Alb & $4.2 \mathrm{~g} / \mathrm{dl}$ \\
$\mathrm{PLT}$ & $23.3 \times 10^{4} / \mathrm{mm}^{3}$ & $\mathrm{GOT}$ & $32 \mathrm{IU} / l$ \\
$\mathrm{Na}$ & $140 \mathrm{mEq} / \mathrm{dl}$ & $\mathrm{GPT}$ & $14 \mathrm{IU} / l$ \\
$\mathrm{~K}$ & $4.5 \mathrm{mEq} / \mathrm{dl}$ & $\mathrm{LDH}$ & $484 \mathrm{IU} / l$ \\
$\mathrm{Cl}$ & $103 \mathrm{mEq} / \mathrm{dl}$ & Glu & $142 \mathrm{mg} / \mathrm{dl}$ \\
& & CRP & $0.2 \mathrm{mg} / \mathrm{dl}$ \\
\hline
\end{tabular}




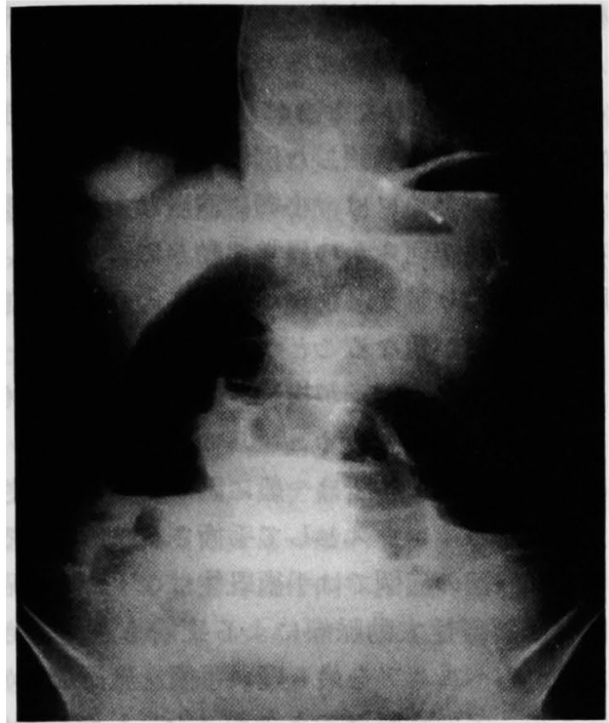

図 1 腹部立位正面単純 X 線所見（5月31日）：小腸 に Niveau 形成がみられ, 上腹部に㹡張腸管像が認 められた。

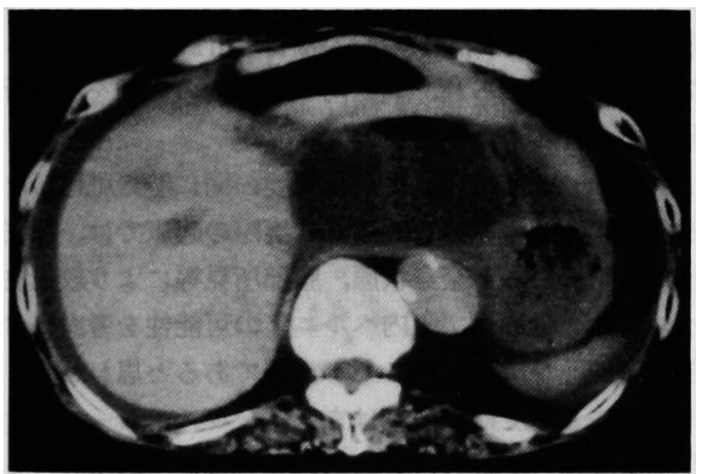

図 2 腹部 CT 所見：胃と肝荗の間の網意と思われる 部位に拡張した腸管像が認められ，また軽度の腹水 が認められた。また解離性大動脈瘤が認められた。

入院後経過：イレウスと診断してイレウスチューブ を挿入した。その後腸液の排液がみられ，腹部膨満は 改善した。また心窝部に圧痛を伴う腫瘤を触れるよう になった。チューブ挿入後 6 日目の小腸造影では，イ レウスチューブはかなり進んでいるが，造影剤は進ま ず上腹部の拡張腸管像は消失しなかった(図 3 ). 保存 的療法でこれ以上は改善しないと考え，内へルニアに よるイレウスを疑い6月10日手術を施行した。

手術所見：正中切開にて開腹すると拡張した小腸が みられ，禁液性の腹水を少量認めた，小腸をたどると

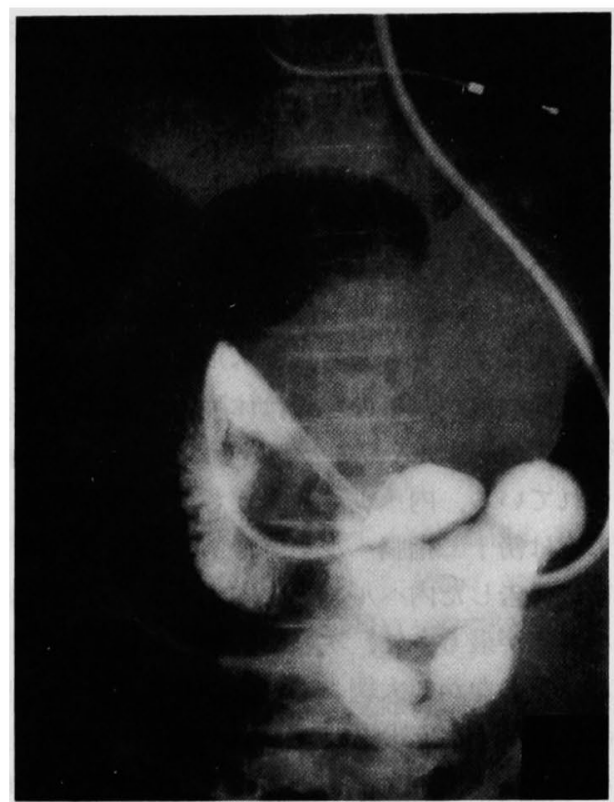

図3小腸造影所見 (6月 8 日, 立位):イレウス チューブはかなり進行したが，造影威は進まず，上 腹部の拡張腸管像は消失しなかった。

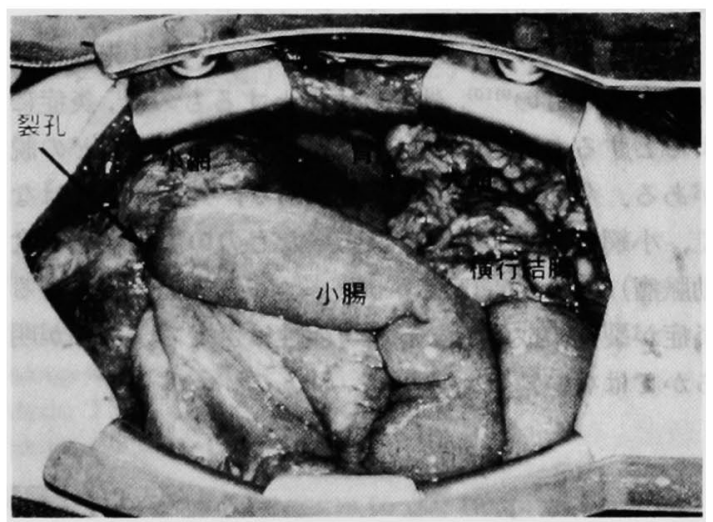

図4手術所見：小網に直径約 $5 \mathrm{~cm}$ の裂孔があり人 ルニア門となり, 小腸が約 $30 \mathrm{~cm}$ 網嘦内に嵌頓して いた.

小網に直径約 $5 \mathrm{~cm} の$ 裂孔がありそれがへルニア門と なり，小腸が網襄内に嵌頓していた(図4).小網と小 腸は癒着しており，小網を一部切除し宿入していた腸 管を用手的に整復し，小網裂孔は広く開けた，回盲部 より $50 \mathrm{~cm} の$ 部位の回腸が約 $30 \mathrm{~cm} に わ た り$ 嵌頓して おり,絞扼痕はあるものの壊死には宿っていなかった。 整復後回腸に異常なくドレーンを择入することなく閉 
腹した，以上より小網裂孔へルニアによるイレウスと 診断した.

術後は順調に経過し，食事摄取や便通も普通となり 4週目に退院した。

\section{考察}

イレウスを起こす疾患のうち内へルニアの頻度は $0.01 \sim 5 \%$ '少ないが, 術前診断が困難で絞拒性イ レウスを起こすこともある.内へルニアは本来のへル ニアとは異なるが，その定義は体腔内の異常に大きい

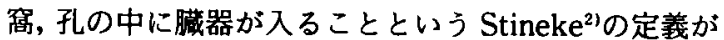
用いられている.内へルニアのうち最も頻度の多いの は欧米では傍十二指腸へルニアであるが3)，高橋ら4が 1980年に報告した内ヘルニアの本邦集計では腸間膜裂 孔ヘルニアが最も多く，次いで傍十二指腸へルニアで あった.そのなかで大網および小網の裂孔を原因とす るものは少なく, 263例中大網によるものは13例, 小網 によるものは 3 例，大・小網によるものが 8 例であっ た，本症例のごとく手術既往がなく小網の異常裂孔を ヘルニア門として網伥へ入り込んだへルニアの症例の 報告は，著者らが集計した結果本邦では 3 例であり， 欧米では 2 例であった(表 2 )。年龄，性に特異的な傾 向はなく，術前に診断できた例はなかった。

大網や小網の裂孔の発生の成因については先天性で あるとするもの ${ }^{9120)}$, 外傷によるとするもの ${ }^{115)}$, 炎症に

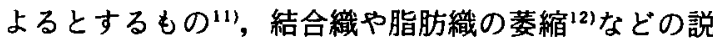
がある. 今回の症例では高齢であり，外傷の既往はな く，小網と小腸との瘦着はあったものの周囲組織（大 動脈瘤）との痹着はなかった，解離性大動脈瘤による 炎症が裂孔の成因となった可能性は否定できないが明 らかではない。

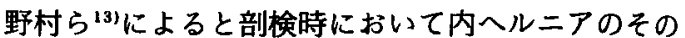
ほとんどが無症状に経過するという。また胃切除後に Billroth I 法で再建したときに小網部は大きな欠損と なっているがそこに嵌頓した例は少ない.したがって 腸閉塞を起こすためには，小網に適当な大きさの裂孔 が存在し，小腸が何らかの異常な動きにより大網，横 行結腸，胃を乗り越え，小腸が裂孔に入り込んで厥頓 するという偶然が重なることが必要と考えられる。し たがっていくつかの因子が複雑に絡み合い, 頻度も少 ないものと思われる。

内ヘルニアの術前診断は一般に困難であり，急性腹 症または単なるイレウスとして手術され診断されるこ とが多い，今回の症例では手術既往はなく，大腸癌も 否定され，解離性大動脈瘤による癒着も否定できな かったが，内へルニアを最も疑い手術を施行したが小 網裂孔へルニアの診断はできなかった。しかし retrospectiveにみると腹部単純 X線で胃泡と同じ高さの 上腹部に拡張腸管が認められ，小網裂孔へルニアを示 す所見の1つであると思われる。深川ら゙も胃小彎上 に挙上した小腸ループのガス像を念頭におくへき所見 としている。また腹部 CT では胃と肝臓の間に搪張し た腸管像が認められ，網蒦内への小腸の嵌頓を示す所 見と思われる。

Tran ら 拡張腸管を認めている。しかし実際の臨床では，局在 診断よりもむしろ全身状態，腹部所見等により絞拒性 イレウスを見逃さず，内ヘルニアの可能性を考慮にお き手術適応を決定することが重要であると思われる。

治療法としては本症例はまずイレウスチューブによ り減圧を行い観察したが改善しないため手術を施行し

表 2 小網裂孔ヘルニア報告例

\begin{tabular}{|c|c|c|c|c|c|c|c|}
\hline $\begin{array}{l}\text { 報告者 } \\
\text { 年度 } \\
\end{array}$ & $\begin{array}{c}\text { 年齢 } \\
\text { 性 }\end{array}$ & 主 訴 & 術前䛦断 & $\begin{array}{c}\text { 手術まての } \\
\text { 期間 }\end{array}$ & 術 式 & 宿入葴器 & 成因 \\
\hline $\begin{array}{l}\text { Gants } \\
1953\end{array}$ & $\begin{array}{l}30 \\
\text { 男 }\end{array}$ & $\begin{array}{l}\text { 上腹部痛 } \\
\text { 腹満 }\end{array}$ & $\begin{array}{l}\text { 横隔膜ヘルニアニア } \\
\text { 内ヘル }\end{array}$ & 3 力月 & 整復 & 胃，横行結腸 & 外第 \\
\hline $\begin{array}{l}\text { 山崎" } \\
1967\end{array}$ & $\begin{array}{l}58 \\
\text { 女 }\end{array}$ & & & & 整復 & 空腸 $1 \mathrm{~m}$ & $\begin{array}{l}\text { 不明 } \\
\text { 胃炎? }\end{array}$ \\
\hline $\begin{array}{l}\text { 深川"7 } \\
1982\end{array}$ & $\begin{array}{l}34 \\
\text { 男 }\end{array}$ & 上腹部痛 & 胃潰痬穿孔 & 12時間 & 小腸切除術 & $\begin{array}{l}\text { 回腸部より } 40 \mathrm{~cm} \\
\text { の小腸 } 50 \mathrm{~cm}\end{array}$ & 不明 \\
\hline $\begin{array}{l}\text { 堀越" } \\
1988\end{array}$ & $\begin{array}{l}54 \\
\text { 女 }\end{array}$ & & イレウス & & & & \\
\hline $\begin{array}{l}\text { Tran') } \\
1991\end{array}$ & $\begin{array}{l}24 \\
\text { 女 }\end{array}$ & $\begin{array}{l}\text { 腹痛 } \\
\text { 㽬昳 }\end{array}$ & 網董へルニア & & 小腸切除術 & $\begin{array}{l}\text { 空腸起始部より } 30 \\
\mathrm{~cm} \text { 小腸 } 150\end{array}$ & 先天性 \\
\hline $\begin{array}{l}\text { 自験例 } \\
1994\end{array}$ & $\begin{array}{l}78 \\
\text { 女 }\end{array}$ & $\begin{array}{l}\text { 腹痛 } \\
\text { 嘕吐 }\end{array}$ & イレウス & 10日 & 整復 & $\begin{array}{l}\text { 回忘部か } 550 \mathrm{~cm} \\
\text { の腸 } 30 \mathrm{~cm}\end{array}$ & 不明 \\
\hline
\end{tabular}


た.一般的な底着性イレウスとは異なり, 腸管が嵌頓 し小腸と小網が痹着していたことから、イレウス チューブによる改善は望めず, 観察期間は短期間て あったほうが良かったかも知れない.手術方法は整復, 塆死に陥っていれば腸管切除など一般的イレウスと変 わらない.今回は整復したのみで，小網裂孔は大きけ れば嵌頓しないと考え，閉鎖せず大きくあけたままに した.

\section{結 語}

小網裂孔による内ヘルニアの 1 例を経験したので報 告した，小網裂孔ヘルニアはまれであり，成因等不明 な点が多い. 診療方針は一般的なイレウスと差はない がイイレウスの診療時には内へルニアの可能性を考慮 におく必要があり,レントゲンゃCT 等の特徴的所見 に注意すべきと思われた。

\section{文献}

1) Mock CJ, Mock HE: Strangulated internal hernia associated with trauma. Arch Surg 77 : $881-886,1958$

2) Stineke CR : Internal hernia. Three additional case reports. Arch Surg 25 : 909-925, 1932

3) Ghahremani GG, Meyers MA : Internal abdominal hernias. Curr Probl Radiol 5: 1-30, 1975

4）高橋英世, 永井米次郎：内ヘルニアによるイレウ ス. 小児外科 $12: 447-453,1980$
5) Gants RT, Ryle JW: Herniation of stomach and colon into omental bursa through a defect in the gastrohepatic ligament. Ann Surg 137 : 285-288, 1953

6）山崎雄弘, 礒橋 保, 大川博之他：網萣内欴頓へル ニアの 2 治験例. 日外会誌 $68: 303,1967$

7）深川裕明, 谷口正哲, 渡辺昌彦他：小網異常裂孔に よる内へルニアの 1 例. 臨外 $37: 1287-1289$, 1982

8）堀越 衛, 中村士郎, 藤井寅夫他：腹腔内ヘルニア の2 例(小網異常裂孔へルニア, 盲腸周囲のヘルニ ア). 日大医誌 $47: 94,1988$

9) Tran TL, Regan F, Al-Kutoubi MAO: Computed tomography of lesser sac hernia through the gastrohepatic omentum. $\mathrm{Br} J$ Radiol 64: 372-374, 1991

10）安藤道夫, 南本智史, 井上光郎他：背側胃間膜裂孔 網蓄ヘルニアの1治験例。外科 $43 ： 417-420$, 1981

11）竹内仁司, 田中耕太郎, 宮田信熙他：大網異常裂孔 ヘルニアの 1 例. 外科診療 $23: 1803-1806,1981$

12）広岡保明, 太田道雄, 池口正英他: 大網異常裂孔へ ルニアによるイレウスの1例. 外科 48：542545,1986

13）野村直孝, 萩原 博, 村田 戒他：絞拒性イレウス で腸切除を施行した内へルニアの1例. 埼玉医会 誌 $20: 499-501,1985$

\title{
A CASE OF LESSER OMENTAL HERNIA
}

\author{
Yoichi KIKUCHI \\ Department of Surgery, Sukagawa Hospital \\ Yoshiro ANDO, Tsuneyuki YOSHIDA, Atsuo TSUCHIYA and Rikiya ABE \\ Second Department of Surgery, Fukushima Medical College
}

A 78-year-old woman who had no past of abdominal surgery or injury came to our hospital because of pain and vomiting. On admission her abdomen was distended and tender. Abdominal X-ray films revealed dilated loops of small intestine in the upper abdomen, and a CT scan showed an intestinal shadow in the omental bursa. An ileus long tube was inserted, but the intestinal shadow did not resolve and we operated suspecting internal hernia. At laparotomy defect in the lesser omentum was found to be a hernia orifice, and $30 \mathrm{~cm}$ of small intestine were incarcerated. The small intestine was not necrotic, so the lesser omentum was partially resected and the small intestine was reduced. The postoperative course was good, and the patient was discharged after 4 weeks.

Internal hernia is rare in ileus, and we have reported an even rarer case of lesser omental hernia along with a review of the literature. There are many unkown aspects of the predisposing causes of lesser omental hernia, but treatment is the same as in any other type of ileus. When caring for ileus patients, the possibility of internal hernia should be kept in mind. We should be alert to the characterisitc X-ray and findings. 